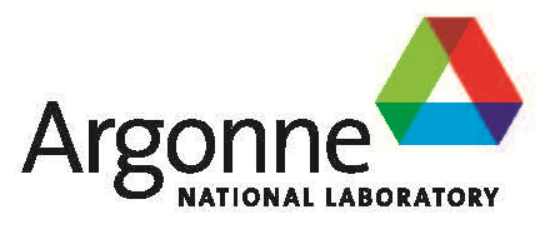

ANL/CSE-14/24

\title{
Plant-Scale Column Designs for SHINE Target Solutions
}

Chemical Sciences and Engineering Division 


\begin{abstract}
About Argonne National Laboratory
Argonne is a U.S. Department of Energy laboratory managed by UChicago Argonne, LLC under contract DE-AC02-06CH11357. The Laboratory's main facility is outside Chicago, at 9700 South Cass Avenue, Argonne, Illinois 60439. For information about Argonne and its pioneering science and technology programs, see www.anl.gov.
\end{abstract}

\title{
DOCUMENT AVAILABILITY
}

Online Access: U.S. Department of Energy (DOE) reports produced after 1991 and a growing number of pre-1991 documents are available free via DOE's SciTech Connect (http://www.osti.gov/scitech/)

Reports not in digital format may be purchased by the public from the National Technical Information Service (NTIS):

U.S. Department of Commerce

National Technical Information Service

5301 Shawnee Rd

Alexandra, VA 22312

unw.ntis.gov

Phone: (800) 553-NTIS (6847) or (703) 605-6000

Fax: (703) 605-6900

Email: orders@ntis.gov

Reports not in digital format are available to DOE and DOE contractors from the Office of Scientific and Technical Information (OST):

U.S. Department of Energy

Office of Scientific and Technical Information

P.O. Box 62

Oak Ridge, TN 37831-0062

unw.osti.gov

Phone: (865) 576-8401

Fax: (865) 576-5728

Email: reports@osti.gov

\begin{abstract}
Disclaimer
This report was prepared as an account of work sponsored by an agency of the United States Government. Neither the United States Government nor any agency thereof, nor UChicago Argonne, LLC, nor any of their employees or officers, makes any warranty, express or implied, or assumes any legal liability or responsibility for the accuracy, completeness, or usefulness of any information, apparatus, product, or process disclosed, or represents that its use would not infringe privately owned rights. Reference herein to any specific commercial product, process, or service by trade name, trademark, manufacturer, or otherwise, does not necessarily constitute or imply its endorsement, recommendation, or favoring by the United States Government or any agency thereof. The views and opinions of document authors expressed herein do not necessarily state or reflect those of the United States Government or any agency thereof, Argonne National Laboratory, or UChicago Argonne, LLC.
\end{abstract}




\section{Plant-Scale Column Designs for SHINE Target Solutions}

by

Amanda J. Youker, Dominique C. Stepinski, Lei Ling, Pei-Lun Chung, and George F. Vandegrift Chemical Sciences and Engineering Division, Argonne National Laboratory

prepared for

U.S. Department of Energy, National Nuclear Security Administration, Office of Defense Nuclear Nonproliferation

September 2014 



\section{CONTENTS}

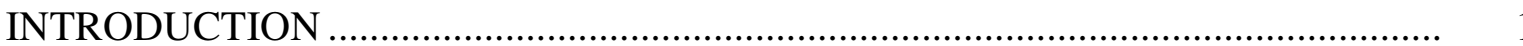

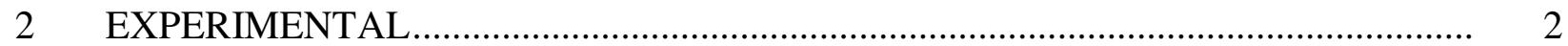

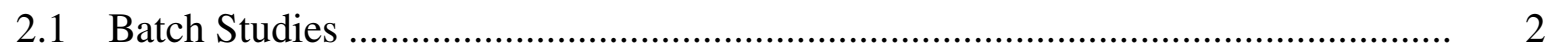

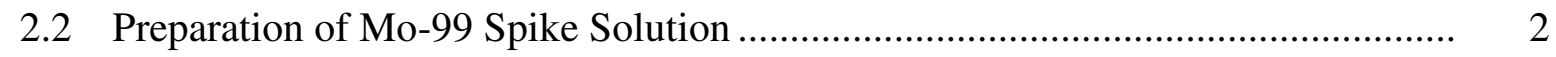

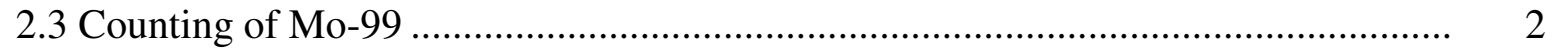

2.4 Uranium Concentration................................................................................. 3

2.5 Column Design Parameters....................................................................... 3

$3 \quad$ LANGMUIR MODEL RESULTS ................................................................... 5

$4 \quad$ RESULTS AND DISCUSSION ................................................................... 8

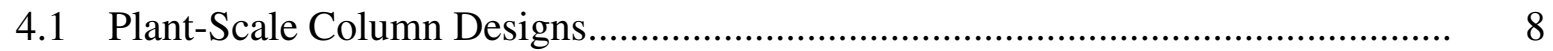

4.2 Down-scale Column Experiments ............................................................. 10

$5 \quad$ CONCLUSIONS AND FUTURE WORK ........................................................... 13

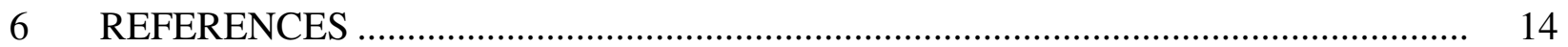

APPENDIX A: Plant-Scale Column Designs for the Potential SHINE Target Solution Configurations with Loading Times of 4 and 6 Hours ............................. 15

\section{FIGURES}

1 Plot of Langmuir Type Adsorption on a Titania Sorbent in the Presence of a $150 \mathrm{~g}-\mathrm{U} / \mathrm{L}$ Uranyl Sulfate Solution with Origin Best Fit at $60^{\circ} \mathrm{C}$

2 Plot of Langmuir Type Adsorption on a Titania Sorbent in the Presence of a $90 \mathrm{~g}-\mathrm{U} / \mathrm{L}$ Uranyl Sulfate Solution with Origin Best Fit at $60^{\circ} \mathrm{C}$

3 Plot of Langmuir Type Adsorption on a Titania Sorbent in the Presence of a $130 \mathrm{~g}-\mathrm{U} / \mathrm{L}$ Uranyl Sulfate Solution with Origin Best Fit at $80^{\circ} \mathrm{C}$ 


\section{TABLES}

1 Calculated Values for the Density and Viscosity of Uranyl Sulfate Solutions at $60^{\circ} \mathrm{C}$ and $80^{\circ} \mathrm{C}$

2 The "a" and "b" Parameters for the Five Target Solutions........................................... 7

3 Target Solution Configurations Being Considered by SHINE ....................................... 8

$4 \quad$ Preliminary Designs for Recovery of Mo from $395 \mathrm{~L}$ of $90 \mathrm{~g}-\mathrm{U} / \mathrm{L}$ and $1.78 \times 10^{-3} \mathrm{mM}$ Mo at $60^{\circ} \mathrm{C}$

$5 \quad$ Preliminary Designs for Recovery of Mo from $257.7 \mathrm{~L}$ of $104.2 \mathrm{~g}-\mathrm{U} / \mathrm{L}$ and $2.35 \times 10^{-3} \mathrm{mM}$ Mo at $60^{\circ} \mathrm{C}$

6 Preliminary Designs for Recovery of Mo from $262 \mathrm{~L}$ of $130 \mathrm{~g}-\mathrm{U} / \mathrm{L}$ and $2.10 \times 10^{-3} \mathrm{mM}$ Mo at $80^{\circ} \mathrm{C}$

$7 \quad$ Preliminary Designs for Recovery of Mo from $178.3 \mathrm{~L}$ of $124.8 \mathrm{~g}-\mathrm{U} / \mathrm{L}$ and $2.98 \times 10^{-3} \mathrm{mM}$ Mo at $60^{\circ} \mathrm{C}$

8 Preliminary Designs for Recovery of Mo from $142.3 \mathrm{~L}$ of $146.8 \mathrm{~g}-\mathrm{U} / \mathrm{L}$ and $3.55 \times 10^{-3} \mathrm{mM}$ Mo at $60^{\circ} \mathrm{C}$

9 Results for the Down-Scale Column Experiments for the Five Target Solution Configurations.

A-1 Preliminary Designs for Recovery of Mo from $395 \mathrm{~L}$ of $90 \mathrm{~g}-\mathrm{U} / \mathrm{L}$ with $1.78 \times 10^{-3} \mathrm{mM}$ Mo at $60^{\circ} \mathrm{C}$

A-2 Preliminary Designs for Recovery of Mo from $395 \mathrm{~L}$ of $90 \mathrm{~g}-\mathrm{U} / \mathrm{L}$ with $1.78 \times 10^{-3} \mathrm{mM}$ Mo at $60^{\circ} \mathrm{C}$

A-3 Preliminary Designs for Recovery of Mo from $257.7 \mathrm{~L}$ of $104.2 \mathrm{~g}$-U/L with $2.35 \times 10^{-3} \mathrm{mM}$ Mo at $60^{\circ} \mathrm{C}$

A-4 Preliminary Designs for Recovery of Mo from $257.7 \mathrm{~L}$ of $104.2 \mathrm{~g}-\mathrm{U} / \mathrm{L}$ with $2.35 \times 10^{-3} \mathrm{mM}$ Mo at $60^{\circ} \mathrm{C}$

A-5 Preliminary Designs for Recovery of Mo from $178.3 \mathrm{~L}$ of $124.8 \mathrm{~g}-\mathrm{U} / \mathrm{L}$ with $2.98 \times 10^{-3} \mathrm{mM}$ Mo at $60^{\circ} \mathrm{C}$

A-6 Preliminary Designs for Recovery of Mo from $178.3 \mathrm{~L}$ of $124.8 \mathrm{~g}-\mathrm{U} / \mathrm{L}$ with 2.98 x $10^{-3} \mathrm{mM}$ Mo at $60^{\circ} \mathrm{C}$ 


\section{TABLES (Cont.)}

A-7 Preliminary Designs for Recovery of Mo from $262 \mathrm{~L}$ of $130 \mathrm{~g}-\mathrm{U} / \mathrm{L}$ with $2.10 \times 10^{-3} \mathrm{mM}$ Mo at $80^{\circ} \mathrm{C}$

A-8 Preliminary Designs for Recovery of Mo from $262 \mathrm{~L}$ of $130 \mathrm{~g}-\mathrm{U} / \mathrm{L}$ with

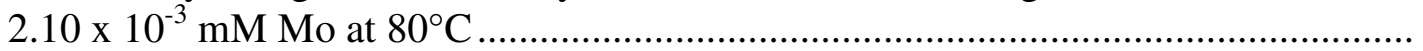

A-9 Preliminary Designs for Recovery of Mo from 142.3 L of $146.8 \mathrm{~g}-\mathrm{U} / \mathrm{L}$ with $3.55 \times 10^{-3} \mathrm{mM}$ Mo at $60^{\circ} \mathrm{C}$

A-10 Preliminary Designs for Recovery of Mo from 142.3 L of 146.8 g-U/L with $3.55 \times 10^{-3} \mathrm{mM}$ Mo at $60^{\circ} \mathrm{C}$ 
This page intentionally left blank 


\section{PLANT-SCALE COLUMN DESIGNS FOR SHINE TARGET SOLUTIONS}

\section{INTRODUCTION}

Argonne is assisting Morgridge Institute for Research (MIR) in their efforts to develop SHINE, which is an accelerator-driven process that will most likely utilize a uranyl sulfate solution for the production of Mo-99. An integral part of the process is the development of a plant-scale column for the separation and recovery of Mo-99. Argonne has collected data from batch studies and small-scale column experiments to input into VERSE (Versatile Reaction Separation), a dynamic simulation package developed by Dr. Linda Wang at Purdue University to design large-scale separation processes using data obtained on a much smaller scale. Plantscale column designs have been generated for several target solution configurations with uranium concentrations varying from 90 to $150 \mathrm{~g}-\mathrm{U} / \mathrm{L}$, Mo concentrations ranging from $1.73 \times 10^{-3}$ to $3.55 \times 10^{-3} \mathrm{mM}$, and solution volumes varying between $142 \mathrm{~L}$ and $395 \mathrm{~L}$. Direct down-scale column results have confirmed the validity of most of the plant-scale designs, because typically less than $1 \%$ Mo is found in the effluent and 90-100 $\pm 5 \%$ Mo can be recovered under the appropriate stripping conditions.

To design a Mo-recovery system for the SHINE project, batch, breakthrough, and pulse tests were conducted to determine isotherm, mass transfer, and system parameters. The VERSE program was used to calculate the mass-transfer zone under various loading times and velocities to design Mo separation and recovery columns employing a pure titania sorbent with 110-micron particles and $60 \AA$ pores. The plant-scale column designs assume a temperature of $60^{\circ} \mathrm{C}$ for most configurations and $80^{\circ} \mathrm{C}$ for feed solutions containing $130 \mathrm{~g}$-U/L uranyl sulfate. VERSEdesigned recovery systems have been tested and verified in laboratory-scale experiments, and it has been shown that this approach is successful. 


\section{EXPERIMENTAL}

\subsection{BATCH STUDIES}

The uptake of Mo(VI) was determined by equilibrating $1 \mathrm{~mL}$ of a Mo-99 spiked aqueous solution with a known amount $(10 \pm 1 \mathrm{mg})$ of sorbent for 24 hours at $60^{\circ} \mathrm{C}$ or $80^{\circ} \mathrm{C}$ using a thermostated shaker bath. Aqueous solutions contained tracer Mo-99 and $10^{-10}-10^{-4} \mathrm{M}$ Mo added as $\mathrm{Na}_{2} \mathrm{MoO}_{4} \cdot 2 \mathrm{H}_{2} \mathrm{O}$ in the presence of uranyl sulfate (90-150 g-U/L). After equilibration, the solution was withdrawn and filtered by using a syringe fitted with a PVDF membrane filter with $0.22-\mu \mathrm{m}$ pore size.

\subsection{PREPARATION OF MO-99 SPIKE SOLUTION}

Molybdenum-99 was obtained from a spent Tc-99m generator (provided by Hot Shots Nuclear Medicine). The initial activity of Mo-99 in a generator is typically between 1 and $10 \mathrm{Ci}$. However, we receive a Tc-99m generator when the activity remaining in the generator is insufficient for patient administration. Typically, a spent Tc-99m generator contains $0.1-0.3 \mathrm{Ci}$ of Mo-99, which is more than enough for our tracer batch and column work.

Molybdenum-99 was removed from the generator by placing a serum vial containing $1 \mathrm{M} \mathrm{NH}_{4} \mathrm{OH}$ on the needle labeled "Saline Charge". Then, an evacuated serum vial was placed on the needle labeled "Receiver". When no more bubbles appeared in the "Receiver" vial, the "Receiver" bottle was removed from the generator. The Mo-99 spiked solution was prepared by bringing the solution to dryness on a hot plate and re-dissolving it in $0.1 \mathrm{M} \mathrm{H}_{2} \mathrm{SO}_{4}$.

\subsection{COUNTING OF MO-99}

The amount of activity in the aqueous samples was determined with a germanium detector. Molybdenum-99 was quantified by measurement of its $739 \mathrm{keV} \gamma$-ray. The activity of Mo-99 in each sample was corrected for decay. The extent of radionuclide uptake in batch studies was expressed in terms of a distribution coefficient, $\mathrm{K}_{\mathrm{d}}$, shown in equation (1).

$$
K_{d}=\left(\frac{A_{o}-A_{s}}{W}\right) / \frac{A_{s}}{V}
$$

Here, $\mathrm{A}_{0}$ and $\mathrm{A}_{\mathrm{s}}$ represent the aqueous phase activity $(\mu \mathrm{Ci})$ before and after equilibration, respectively, $\mathrm{W}$ is the dry weight of the sorbent $(\mathrm{g})$, and $\mathrm{V}$ is the volume of the aqueous phase $(\mathrm{mL})$. 


\subsection{URANIUM CONCENTRATION}

Inductively coupled optical emission spectroscopy (ICP-OES) was used to determine the concentration of uranium, and the error associated with these measurements is $\pm 5 \%$.

\subsection{COLUMN DESIGN PARAMETERS}

The parameters and physical properties of uranyl sulfate given below were input into VERSE to design the plant-scale columns for the five target solution configurations being considered by SHINE. Table 1 shows the calculated density and viscosity values for the different uranyl sulfate solutions. Note the following:

1. The sorbent used for the Mo-recovery column is S110, a pure titania sorbent with 110 micron particles and $60 \AA$ pores.

2. Langmuir isotherm parameters were estimated from Mo batch data measured for solutions with varying Mo concentrations in solutions containing 90 and $150 \mathrm{~g}-\mathrm{U} / \mathrm{L}$ uranyl sulfate at $60^{\circ} \mathrm{C}$ and $130 \mathrm{~g}-\mathrm{U} / \mathrm{L}$ uranyl sulfate at $80^{\circ} \mathrm{C}$.

3. The Brownian diffusivity $\left(D_{\infty}\right)$ value of $\mathrm{HMoO}_{4}{ }^{-}$in water at $25^{\circ} \mathrm{C}$ (viscosity $=0.8851 \mathrm{cP}$ ) was reported to be $8.3 \times 10^{-4} \mathrm{~cm}^{2} / \mathrm{min} .{ }^{1,2}$

4. The density of a $130 \mathrm{~g}-\mathrm{U} / \mathrm{L}$ uranyl-sulfate solution at $\mathrm{pH} 1$ was determined experimentally to be $1.16 \mathrm{~g} / \mathrm{mL}$ at $80{ }^{\circ} \mathrm{C}$. The densities of the remaining solutions were calculated by fitting data found in the literature. ${ }^{3,4}$ (See Table 1.)

5. Viscosities for the target solutions were estimated by fitting published data obtained at $20.0,30.0,44.8,59.8,75.0$, and $90.0{ }^{\circ} \mathrm{C} .{ }^{5}$ (See Table 1.)

6. The axial dispersion $(E b)$ was estimated with the Chung and Wen correlation (1968). ${ }^{6}$

7. The mass transfer coefficient $(k f)$ was estimated with the Wilson and Geankoplis data (1966). ${ }^{7}$

8. Sorbent intra-particle voidage was obtained from the manufacturer, $\varepsilon p=0.40$. Total void fraction, $\varepsilon t$, was determined experimentally to be 0.608 and interparticle voidage $(\varepsilon b)$ was calculated to be $0.35(\varepsilon t=\varepsilon b+\varepsilon p \times(1-\varepsilon b))$. 
TABLE 1 Calculated Values for the Density and Viscosity of Uranyl Sulfate Solutions at $60^{\circ} \mathrm{C}$ and $80^{\circ} \mathrm{C}$

\begin{tabular}{cccc}
\hline & $\begin{array}{c}\text { Density } \\
(\rho)(\mathrm{g} / \mathrm{mL})\end{array}$ & $\begin{array}{c}\text { Viscosity }(\mu) \\
(\mathrm{cP})\end{array}$ & $\begin{array}{c}\text { Temperature } \\
\left({ }^{\circ} \mathrm{C}\right)\end{array}$ \\
\hline Conc. $(\mathrm{g}-\mathrm{U} / \mathrm{L})$ & & & \\
90 & 1.1 & 0.59 & 60 \\
104.2 & 1.12 & 0.61 & 60 \\
130 & $1.16^{*}$ & 0.47 & 80 \\
124.8 & 1.15 & 0.64 & 60 \\
146.8 & 1.18 & 0.68 & 60 \\
\hline
\end{tabular}

* Value was determined experimentally using a MettlerToledo density meter. 


\section{LANGMUIR MODEL RESULTS}

The uptake of Mo was determined in a batch mode as a function of increasing Mo concentration. It was shown previously that Mo adsorption on titania sorbents follows Langmuir behavior. ${ }^{8}$ There are four basic assumptions associated with the Langmuir model:

1. All adsorption sites are equal.

2. Adsorbing species do not interact with each other.

3. The adsorption mechanism does not vary for the same species.

4. The adsorbing species will form a single monolayer and only occupy free adsorption sites. ${ }^{8}$

The Langmuir-type adsorption is modeled by equation (2), where $\mathrm{q}_{\mathrm{i}}$ represents the amount of species $i$ adsorbed on the sorbent, $a_{i}$ is the linear isotherm parameter, $b_{i}$ is the nonlinear isotherm parameter, and $\mathrm{C}_{\mathrm{i}}$ represents the aqueous-phase concentration of $\mathrm{i}$ in equilibrium with $\mathrm{q}_{\mathrm{i}}$.

$$
\mathrm{q}_{\mathrm{i}}=\frac{\mathrm{a}_{\mathrm{i}} * \mathrm{C}_{\mathrm{i}}}{\left(1+\mathrm{b}_{\mathrm{i}} \mathrm{C}_{\mathrm{i}}\right)}
$$

Langmuir-type data were obtained in solutions containing 90 and $150 \mathrm{~g}-\mathrm{U} / \mathrm{L}$ uranyl sulfate at $60^{\circ} \mathrm{C}$ and $130 \mathrm{~g}-\mathrm{U} / \mathrm{L}$ at $80^{\circ} \mathrm{C}$. Figures $1-3$ show the Langmuir data obtained in uranyl sulfate solutions containing $150 \mathrm{~g}-\mathrm{U} / \mathrm{L}$ at $60^{\circ} \mathrm{C}, 90 \mathrm{~g}-\mathrm{U} / \mathrm{L}$ at $60^{\circ} \mathrm{C}$, and $130 \mathrm{~g}-\mathrm{U} / \mathrm{L}$ at $80^{\circ} \mathrm{C}$. The data were fit to the Langmuir model using Origin 8.5.1. Table 2 shows the "a" linear and "b" non-linear parameters input into VERSE to design the plant-scale columns for the five target solutions (see Section 4.1). The same "a" and "b" values obtained in a $90 \mathrm{~g}-\mathrm{U} / \mathrm{L}$ uranyl sulfate solution were used to generate column designs for a $104.2 \mathrm{~g}-\mathrm{U} / \mathrm{L}$ uranyl sulfate solution.

Additionally, the same "a" and "b" values obtained in a $150 \mathrm{~g}-\mathrm{U} / \mathrm{L}$ uranyl sulfate solution were used to generate column designs for a 124.8 and a $146.8 \mathrm{~g}-\mathrm{U} / \mathrm{L}$ uranyl sulfate solution. 


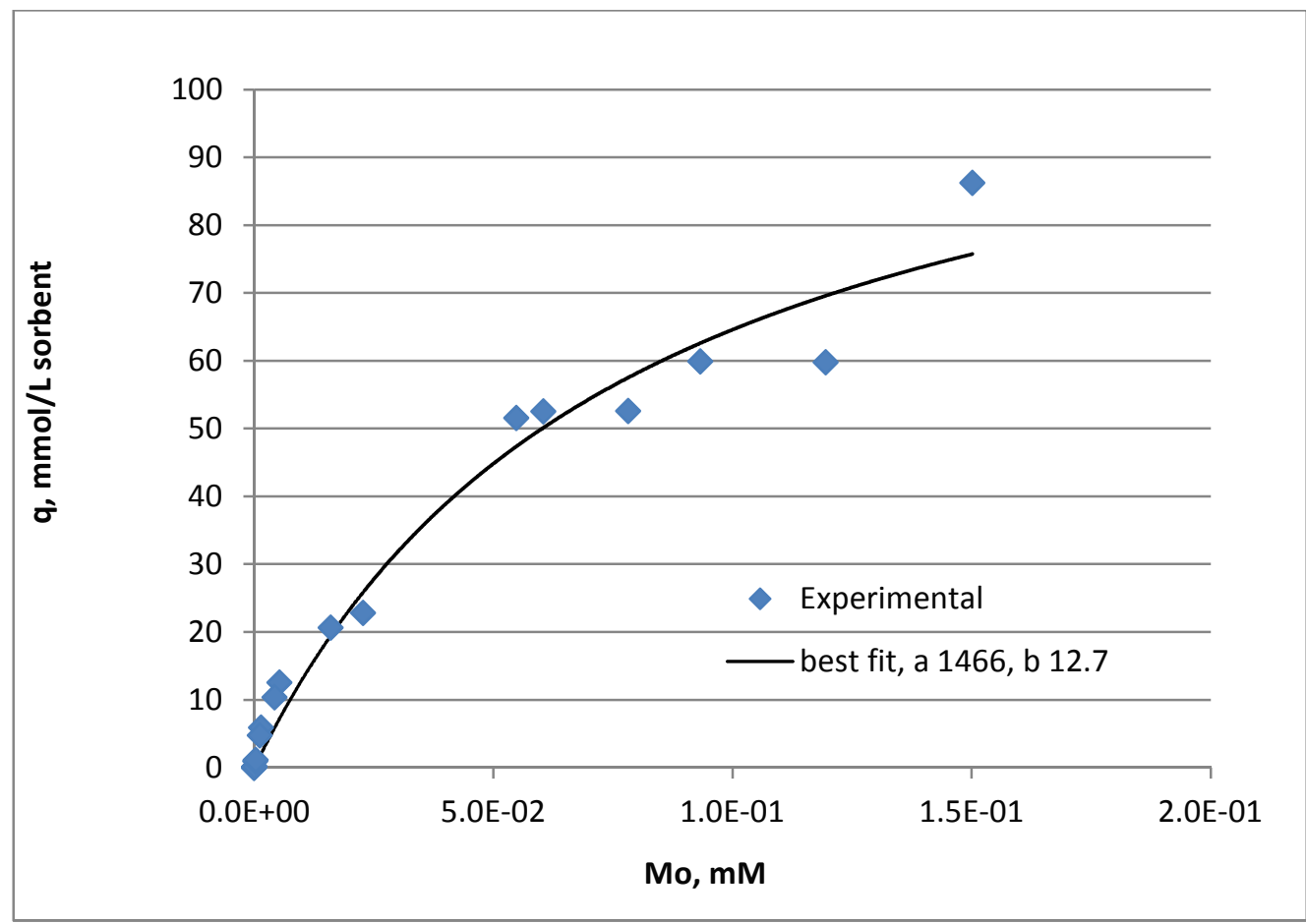

FIGURE 1 Plot of Langmuir Type Adsorption on a Titania Sorbent in the Presence of a $150 \mathrm{~g}-\mathrm{U} / \mathrm{L}$ Uranyl Sulfate Solution with Origin Best Fit at $60^{\circ} \mathrm{C}$

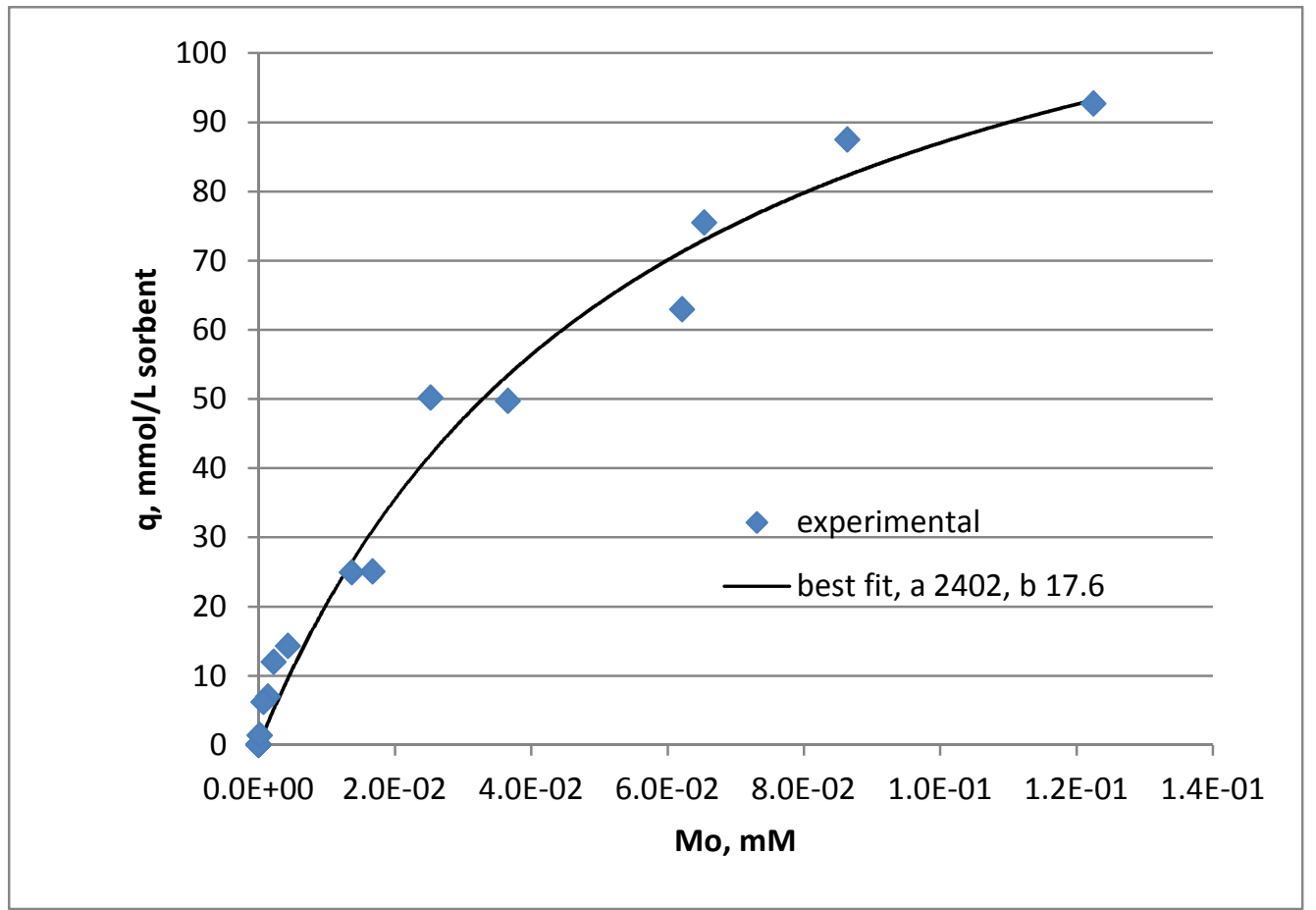

FIGURE 2 Plot of Langmuir Type Adsorption on a Titania Sorbent in the Presence of a $90 \mathrm{~g}-\mathrm{U} / \mathrm{L}$ Uranyl Sulfate Solution with Origin Best Fit at $60^{\circ} \mathrm{C}$ 


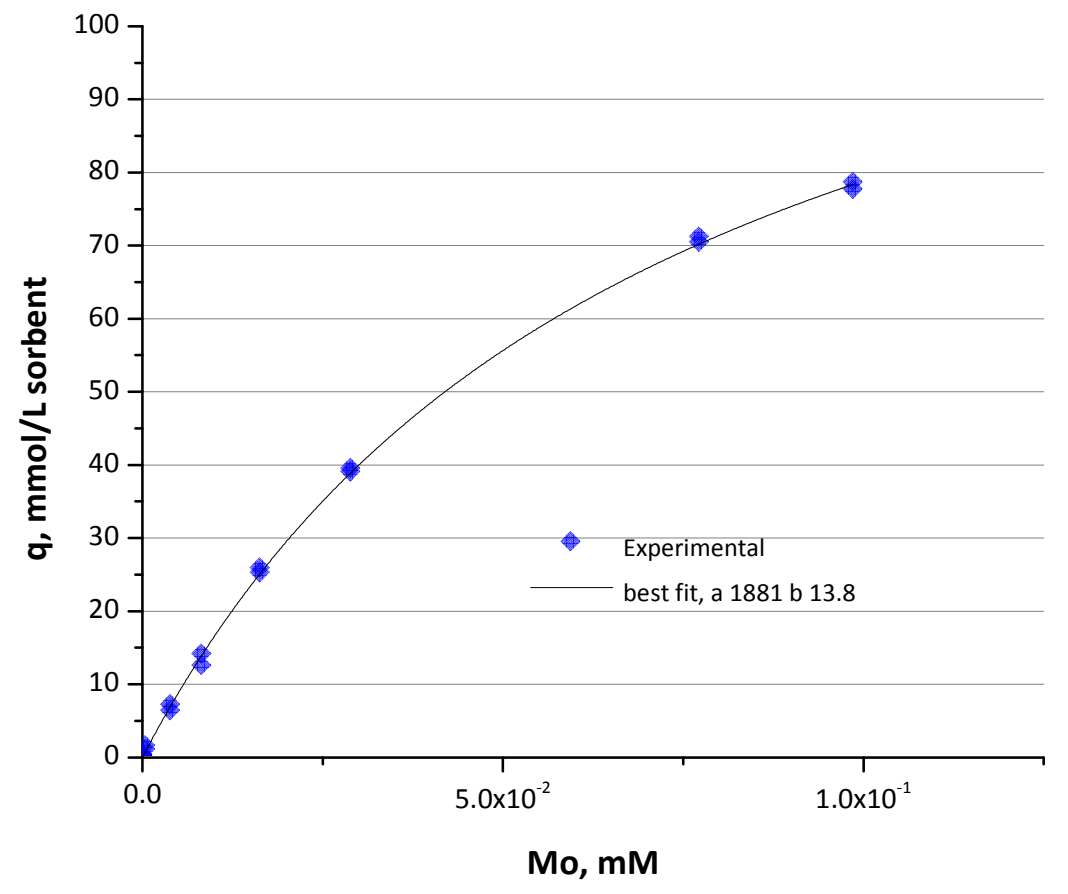

FIGURE 3 Plot of Langmuir Type Adsorption on a Titania Sorbent in the Presence of a $130 \mathrm{~g}-\mathrm{U} / \mathrm{L}$ Uranyl Sulfate Solution with Origin Best Fit at $80^{\circ} \mathrm{C}$

TABLE 2 The "a" and "b" Parameters for the Five Target Solutions

\begin{tabular}{cccc}
\hline $\begin{array}{c}\text { U Concentration } \\
\text { (g-U/L) }\end{array}$ & $\begin{array}{c}\text { Temperature } \\
\left({ }^{\circ} \mathrm{C}\right)\end{array}$ & $\begin{array}{c}\text { Langmuir } \\
\text { "a" value }\end{array}$ & $\begin{array}{c}\text { Langmuir } \\
\text { "b" value } \\
\left(\mathrm{mM}^{-1}\right)\end{array}$ \\
\hline 90 & 60 & 2402 & 17.6 \\
104.2 & 60 & 2402 & 17.6 \\
124.8 & 60 & 1466 & 12.7 \\
130 & 80 & 1881 & 13.8 \\
146.8 & 60 & 1466 & 12.7 \\
\hline
\end{tabular}




\section{RESULTS AND DISCUSSION}

\subsection{PLANT-SCALE COLUMN DESIGNS}

Table 3 shows the five target solution configurations being considered by SHINE Medical Technologies for the production of Mo-99. Potential column designs were developed for loading the target solution onto the column over periods of 2, 4, and 6 hours. Tables 4-8 show the potential column designs for the different configurations with a loading time of 2 hours. In these tables, the mass-transfer zone (MTZ) was calculated for each column diameter based on the linear velocity required to complete loading the column in the specified time period. The column length was increased by $10 \%$ above the MTZ and rounded up to the nearest centimeter to account for system parameter uncertainties. The column volume, mass of sorbent, pressure drop, and sorbent loading were calculated from the column geometry. Plant-scale column designs for the different configurations with loading times of 4 and 6 hours are shown in Appendix A.

Even though the sorbent utilization for the different configurations can be increased by $28-32 \%$ by increasing the loading time from 2 to 4 hours and by $42-44 \%$ by increasing the loading time from 2 to 6 hours, we decided saving time was more important than using less sorbent. The optimal column designs being considered and tested on a laboratory scale are for a

TABLE 3 Target Solution Configurations Being Considered by SHINE

\begin{tabular}{cccccc}
\hline $\begin{array}{c}\text { Uranyl Sulfate } \\
\text { Conc. (g-U/L) }\end{array}$ & Vol. (L) & $\begin{array}{c}\text { Fission Power } \\
(\mathrm{kW})\end{array}$ & $\begin{array}{c}\text { Mo } \\
(\mathrm{mmol})\end{array}$ & Mo $(\mathrm{mM})$ & Mo-99 (Ci) \\
\hline & & & & & \\
90 & 395 & 112.7 & $7.03 \mathrm{E}-01$ & $1.78 \mathrm{E}-03$ & 5000 \\
104.2 & 257.7 & 97.2 & $6.06 \mathrm{E}-01$ & $2.35 \mathrm{E}-03$ & 4313 \\
130 & 262 & 87.5 & $5.50 \mathrm{E}-01$ & $2.10 \mathrm{E}-03$ & 3882 \\
124.8 & 178.3 & 85.1 & $5.31 \mathrm{E}-01$ & $2.98 \mathrm{E}-03$ & 3776 \\
146.8 & 142.3 & 80.9 & $5.05 \mathrm{E}-01$ & $3.55 \mathrm{E}-03$ & 3589 \\
\hline
\end{tabular}

TABLE 4 Preliminary Designs for Recovery of Mo from $395 \mathrm{~L}$ of $90 \mathrm{~g}-\mathrm{U} / \mathrm{L}$ and $1.78 \times 10^{-3} \mathrm{mM}$ Mo at $60^{\circ} \mathrm{C}(\mathrm{S110}, 99.9 \%$ recovery, 2-h loading time, 3.3-L/min rate)

\begin{tabular}{cccccccc}
\hline Column & $\begin{array}{c}\text { Velocity } \\
\text { ID }(\mathrm{cm})\end{array}$ & $\begin{array}{c}\mathrm{MTZ}_{0.1 \%} \\
(\mathrm{~cm})\end{array}$ & $\begin{array}{c}\text { Column } \\
\text { Length } \\
(\mathrm{cm})\end{array}$ & $\begin{array}{c}\text { Column } \\
\text { Volume } \\
(\mathrm{mL})\end{array}$ & $\begin{array}{c}\text { Sorbent } \\
\text { Weight } \\
(\mathrm{g})\end{array}$ & $\begin{array}{c}\Delta \mathrm{P} \\
(\mathrm{atm})\end{array}$ & $\begin{array}{c}\text { Mo- } \\
99 / \text { Sorbent } \\
\text { Mass (Ci/g) }\end{array}$ \\
\hline & & & & & & & \\
12 & 29.1 & 18.25 & 20 & 2262 & 2941 & 0.87 & 1.70 \\
15 & 18.63 & 11.77 & 13 & 2297 & 2986 & 0.36 & 1.67 \\
20 & 10.48 & 6.73 & 8 & 2513 & 3267 & 0.13 & 1.53 \\
25 & 6.71 & 4.39 & 5 & 2454 & 3191 & 0.05 & 1.57 \\
30 & 4.66 & 3.13 & 4 & 2827 & 3676 & 0.03 & 1.36 \\
\hline
\end{tabular}


TABLE 5 Preliminary Designs for Recovery of Mo from $257.7 \mathrm{~L}$ of $104.2 \mathrm{~g}-\mathrm{U} / \mathrm{L}$ and $2.35 \times 10^{-3} \mathrm{mM}$ Mo at $60^{\circ} \mathrm{C}(\mathrm{S110}, 99.9 \%$ recovery, 2-h loading time, 2.1-L/min rate)

\begin{tabular}{cccccccc}
\hline Column & $\begin{array}{c}\text { Velocity } \\
(\mathrm{cm} / \mathrm{min})\end{array}$ & $\begin{array}{c}\text { MTZ } 0.1 \% \\
(\mathrm{~cm})\end{array}$ & $\begin{array}{c}\text { Column } \\
\text { Length } \\
(\mathrm{cm})\end{array}$ & $\begin{array}{c}\text { Column } \\
\text { Volume } \\
(\mathrm{mL})\end{array}$ & $\begin{array}{c}\text { Sorbent } \\
\text { Weight } \\
(\mathrm{g})\end{array}$ & $\Delta \mathrm{P}(\mathrm{atm})$ & $\begin{array}{c}\text { Mo-99/Sorbent } \\
\text { Mass (Ci/g) }\end{array}$ \\
\hline & & & & & & & \\
12 & 18.99 & 12.28 & 13 & 1470 & 1911 & 0.38 & 2.26 \\
15 & 12.15 & 7.93 & 9 & 1590 & 2068 & 0.17 & 2.09 \\
20 & 6.84 & 4.53 & 5 & 1571 & 2042 & 0.05 & 2.11 \\
30 & 3.04 & 2.13 & 3 & 2121 & 2757 & 0.01 & 1.56 \\
\hline
\end{tabular}

TABLE 6 Preliminary Designs for Recovery of Mo from $262 \mathrm{~L}$ of $130 \mathrm{~g}-\mathrm{U} / \mathrm{L}$ and $2.10 \times 10^{-3} \mathrm{mM}$ Mo at $80^{\circ} \mathrm{C}(\mathrm{S110}, 99.9 \%$ recovery, $2-\mathrm{h}$ loading time, $2.2-\mathrm{L} / \mathrm{min}$ rate $)$

\begin{tabular}{cccccccc}
\hline Column & $\begin{array}{c}\text { Velocity } \\
(\mathrm{cm} / \mathrm{min})\end{array}$ & $\begin{array}{c}\mathrm{MTZ}_{0.1 \%} \\
(\mathrm{~cm})\end{array}$ & $\begin{array}{c}\text { Column } \\
\text { Length } \\
(\mathrm{cm})\end{array}$ & $\begin{array}{c}\text { Column } \\
\text { Volume } \\
(\mathrm{L})\end{array}$ & $\begin{array}{c}\text { Sorbent } \\
\text { Weight } \\
(\mathrm{kg})\end{array}$ & $\Delta \mathrm{P}(\mathrm{atm})$ & $\begin{array}{c}\text { Mo-99/ } \\
\text { Sorbent } \\
\text { Mass }(\mathrm{Ci} / \mathrm{g})\end{array}$ \\
\hline & & & & & & & \\
10 & 27.82 & 17.36 & 20 & 1.6 & 2.04 & 0.63 & 1.90 \\
12 & 19.32 & 12.04 & 14 & 1.6 & 2.06 & 0.30 & 1.89 \\
15 & 12.37 & 7.80 & 9 & 1.6 & 2.07 & 0.13 & 1.88 \\
20 & 6.96 & 4.43 & 5 & 1.6 & 2.04 & 0.04 & 1.90 \\
\hline
\end{tabular}

TABLE 7 Preliminary Designs for Recovery of Mo from 178.3 L of 124.8 g-U/L and $2.98 \times 10^{-3} \mathrm{mM}$ Mo at $60^{\circ} \mathrm{C}(\mathrm{S110}, 99.9 \%$ recovery, $2-\mathrm{h}$ loading time, $1.5-\mathrm{L} / \mathrm{min}$ rate)

\begin{tabular}{cccccccc}
\hline Column & $\begin{array}{c}\text { Velocity } \\
(\mathrm{cm} / \mathrm{min})\end{array}$ & $\begin{array}{c}\mathrm{MTZ}_{0.1 \%} \\
(\mathrm{~cm})\end{array}$ & $\begin{array}{c}\text { Column } \\
\text { Length } \\
(\mathrm{cm})\end{array}$ & $\begin{array}{c}\text { Column } \\
\text { Volume } \\
(\mathrm{mL})\end{array}$ & $\begin{array}{c}\text { Sorbent } \\
\text { Weight } \\
(\mathrm{g})\end{array}$ & $\Delta \mathrm{P}(\mathrm{atm})$ & $\begin{array}{c}\text { Mo-99/Sorbent } \\
\text { Mass }(\mathrm{Ci} / \mathrm{g})\end{array}$ \\
\hline & & & & & & & \\
10 & 18.92 & 15.66 & 17 & 1335 & 1736 & 0.53 & 2.18 \\
15 & 8.41 & 7.07 & 8 & 1414 & 1838 & 0.11 & 2.05 \\
20 & 4.73 & 4.06 & 5 & 1571 & 2042 & 0.04 & 1.85 \\
25 & 3.03 & 2.67 & 3.5 & 1718 & 2233 & 0.02 & 1.69 \\
\hline
\end{tabular}


TABLE 8 Preliminary Designs for Recovery of Mo from $142.3 \mathrm{~L}$ of $146.8 \mathrm{~g}-\mathrm{U} / \mathrm{L}$ and $3.55 \times 10^{-3} \mathrm{mM}$ Mo at $60^{\circ} \mathrm{C}(\mathrm{S110}, 99.9 \%$ recovery, 2-h loading time, $1.2-\mathrm{L} / \mathrm{min}$ rate $)$

\begin{tabular}{cccccccc}
\hline Column & $\begin{array}{c}\text { Velocity } \\
(\mathrm{cm} / \mathrm{min})\end{array}$ & $\begin{array}{c}\mathrm{MTZ}_{0.1 \%} \\
(\mathrm{~cm})\end{array}$ & $\begin{array}{c}\text { Column } \\
\text { Length } \\
(\mathrm{cm})\end{array}$ & $\begin{array}{c}\text { Column } \\
\text { Volume } \\
(\mathrm{mL})\end{array}$ & $\begin{array}{c}\text { Sorbent } \\
\text { Weight } \\
(\mathrm{g})\end{array}$ & $\begin{array}{c}\Delta \mathrm{P} \\
(\mathrm{atm})\end{array}$ & $\begin{array}{c}\text { Mo-99/Sorbent } \\
\text { Mass }(\mathrm{Ci} / \mathrm{g})\end{array}$ \\
\hline & & & & & & & \\
10 & 15.1 & 12.97 & 14 & 1100 & 1429 & 0.37 & 2.51 \\
12 & 10.49 & 9.07 & 10 & 1131 & 1470 & 0.18 & 2.44 \\
15 & 6.71 & 5.87 & 7 & 1237 & 1608 & 0.08 & 2.23 \\
20 & 3.77 & 3.39 & 4 & 1257 & 1634 & 0.03 & 2.20 \\
\hline
\end{tabular}

loading time of 2 hours. Another way to increase sorbent utilization is to decrease Mo recovery from $99.9 \%$ to $99 \%$ in VERSE, but that option is not being pursued. From a separation and recovery standpoint, the optimal configuration should have the highest Mo concentration and lowest feed volume. The target solution that looks most promising is $146.8 \mathrm{~g}-\mathrm{U} / \mathrm{L}$ because it has the best sorbent utilization and smallest column sizes. Lowering the column volume has at least two benefits: (1) decreasing the volume and mass of the spent column material in the waste and (2) lowering the volumes of the column wash streams and the Mo-product stream.

Under the conditions modeled in this study, the calculated mass transfer area is nearly proportional to the inverse of the linear velocity. Therefore, the geometry of the column, as long as the volume is kept constant, is not a key factor. The column geometry should be sized for easy, reliable packing to maintain the pressure drop in the column relatively low and to accommodate other economic and operational factors.

Based on having the column pressure drop below $0.5 \mathrm{~atm}$ and a column geometry that can be easily and reliably packed, the following is suggested:

- For recovery of Mo in 2 hours, the recommended column is $10 \times 14 \mathrm{~cm}$ (ID $x$ L) utilizing $\sim 1.4 \mathrm{~kg}$ of sorbent with a $\Delta \mathrm{P}=0.37 \mathrm{~atm}$. The projected acid wash volume for this design is $5.5 \mathrm{~L}$, water wash is $5.5 \mathrm{~L}$, and the Mo-product volume is $22-33 \mathrm{~L}$.

\subsection{DOWN-SCALE COLUMN EXPERIMENTS}

Several laboratory-scale column experiments were performed in an effort to test the plant-scale column designs derived from VERSE calculations. The column sizes that were tested were chosen based on the availability of the columns and the amount of feed volume. Results from 1 to 4 down-scale experiments are shown in Table 9 for each of the different target solution configurations being considered by SHINE. All column experiments employed a depleted uranium solution as uranyl sulfate $(\mathrm{pH} 1)$ with stable Mo at the specified concentration added as sodium molybdate and tracer Mo-99. 
TABLE 9 Results for the Down-Scale Column Experiments for the Five Target Solution Configurations

\begin{tabular}{|c|c|c|c|c|c|c|c|c|c|}
\hline $\begin{array}{l}\text { U Conc. } \\
(\mathrm{g}-\mathrm{U} / \mathrm{L})\end{array}$ & $\begin{array}{l}\text { Mo Conc. } \\
(\mathrm{mM})\end{array}$ & $\begin{array}{c}\text { Feed } \\
\text { Volume } \\
(\mathrm{mL})\end{array}$ & $\begin{array}{l}\text { Column } \\
\text { ID }(\mathrm{cm}) \\
\end{array}$ & $\begin{array}{l}\text { Column } \\
\mathrm{L}(\mathrm{cm})\end{array}$ & $\begin{array}{c}\% \text { Mo } \\
\text { Effluent }\end{array}$ & $\begin{array}{c}\% \text { Mo } \\
\text { Recovered }\end{array}$ & $\begin{array}{l}\text { Loading } \\
\text { Velocity } \\
(\mathrm{cm} / \mathrm{min}) \\
\end{array}$ & $\begin{array}{l}\text { Stripping } \\
\text { Velocity } \\
(\mathrm{cm} / \mathrm{min})\end{array}$ & $\begin{array}{c}\text { Feed } \\
\text { Temp. } \\
\left({ }^{\circ} \mathrm{C}\right) \\
\end{array}$ \\
\hline 90 & $1.73 \mathrm{E}-03$ & 441 & 1 & 8 & 0.3 & $82 *$ & 5 & 5 & 60 \\
\hline 90 & $1.73 \mathrm{E}-03$ & 288 & 1 & 5 & 1.0 & 90 & 3 & 3 & 60 \\
\hline 90 & $1.73 \mathrm{E}-03$ & 372 & 1 & 5 & 0.7 & 100 & 4 & 4 & 60 \\
\hline 90 & $1.73 \mathrm{E}-03$ & 468 & 1 & 5 & 1.1 & 94 & 5 & 5 & 60 \\
\hline 104 & $2.35 \mathrm{E}-03$ & 504 & 1 & 3 & 0.2 & 96 & 3.1 & 1.6 & 60 \\
\hline 125 & $2.98 \mathrm{E}-03$ & 196 & 0.66 & 5 & 0.1 & 100 & 4.7 & 2.3 & 60 \\
\hline 130 & $2.10 \mathrm{E}-03$ & 665 & 1 & 5 & 0.08 & 100 & 7 & 3.5 & 80 \\
\hline 130 & $2.10 \mathrm{E}-03$ & 665 & 1 & 5 & 0.11 & 86 & 7 & 7 & 80 \\
\hline 130 & $2.10 \mathrm{E}-03$ & 665 & 1 & 5 & 0.33 & $81^{* *}$ & 7 & 3.5 & 80 \\
\hline 146 & $3.55 \mathrm{E}-03$ & 364 & 1 & 4 & 0.66 & 92 & 3.8 & 1.9 & 60 \\
\hline 146 & $3.55 \mathrm{E}-03$ & 364 & 1 & 4 & 0.1 & 66 & 3.8 & 3.8 & 60 \\
\hline
\end{tabular}

The feed solution was heated to 60 or $80^{\circ} \mathrm{C}$ prior to being loaded onto the column. The column was kept at 60 or $80^{\circ} \mathrm{C}$ using heat tape, and stainless steel coils wrapped in heat tape were placed immediately before and after the column inlet and outlet to ensure the temperature of the solution entering the column was maintained at 60 or $80^{\circ} \mathrm{C}$. The strip solution was heated to $70^{\circ} \mathrm{C}$ to achieve optimal Mo recovery because lower Mo recoveries were observed when the strip solution was kept at room temperature or heated to temperatures $\geq 80^{\circ} \mathrm{C}$. Each column experiment was performed as follows:

1. Column was equilibrated with 10 column volumes (CVs) of $0.1 \mathrm{M} \mathrm{H}_{2} \mathrm{SO}_{4}$.

2. Feed solution (heated to the appropriate temperature) was loaded onto the column at a specific linear velocity in the up-flow direction (to concentrate Mo on the bottom of the column and prevent entrapment of fission gases for future column runs with irradiated solutions).

3. Column was washed with $5 \mathrm{CVs}$ of $1 \mathrm{M} \mathrm{H}_{2} \mathrm{SO}_{4}$ in the up-flow direction (to ensure any adsorbed $\mathrm{Pu}$ is removed from the column for future runs with irradiated solutions).

4. Column was washed with $5 \mathrm{CVs}$ of $\mathrm{H}_{2} \mathrm{O}$ in the up-flow direction (to remove any acid).

5. Molybdenum was eluted by passing $30 \mathrm{CVs}$ of $1 \mathrm{M} \mathrm{NH}_{4} \mathrm{OH}$ heated to $70^{\circ} \mathrm{C}$ through the column in the down-flow direction. 
6. Column was washed with $5 \mathrm{CVs}$ of $\mathrm{H}_{2} \mathrm{O}$ in the up-flow direction. A freshly packed titania column was used for each experiment.

The plant-scale column designs generated using VERSE assume 99.9\% Mo will be adsorbed and recovered. Direct down-scale column experiments show that $0.1-1.1 \%$ (standard deviation of $\pm 5 \%$ of the $0.1-1.1 \%$ ) Mo is found in the effluent. Due to the error associated with the gamma counting results, $1 \%$ or less Mo in the effluent indicates good Mo adsorption and effective column design.

The Mo recoveries ranged from $66-100 \%( \pm 5 \%)$ for the down-scale column experiments. Results from these experiments suggest that the stripping velocity should be half of the loading velocity to achieve $90-100 \%( \pm 5 \%)$ recovery of Mo. For example, only $66 \%$ Mo was recovered when the loading and strip velocities were the same for the $146 \mathrm{~g}-\mathrm{U} / \mathrm{L}$ experiment; however, $92 \%$ Mo was recovered when the linear velocity for the strip solution was decreased from 3.8 to $1.9 \mathrm{~cm} / \mathrm{min}$. Additionally, the temperature of the strip solution should be maintained at $70^{\circ} \mathrm{C}$ to ensure diffusion into the sorbent pores and release of Mo. For example, $82 \%$ Mo was recovered for the $90 \mathrm{~g}$-U/L experiment when the strip solution was not heated, and $81 \%$ Mo was recovered for the $130 \mathrm{~g}-\mathrm{U} / \mathrm{L}$ experiment when the strip solution was heated to $80^{\circ} \mathrm{C}$. Moreover, $100 \%$ Mo was recovered under the same conditions for the $130 \mathrm{~g}-\mathrm{U} / \mathrm{L}$ experiment when the strip solution was heated to $70^{\circ} \mathrm{C}$. When the temperature of the strip solution exceeds $\sim 70^{\circ} \mathrm{C}$, a significant number of bubbles form and are subsequently passed through the column, decreasing the amount of Mo recovered.

For the plant-scale operation, recovering $~ 80-85 \%$ of the Mo actually formed after purification will be viewed as a success. Since the expected Mo yield for the LEU-Modified Cintichem purification process is between 85 and $90 \%$, the operation must recover $95 \%$ of the Mo. The column experiments completed thus far have not studied the effects of other fission and activation products on Mo adsorption and recovery or the effects of a high radiation field on the Mo redox chemistry. The mini-SHINE experiments will examine the effects of potential competing components on Mo adsorption and recovery because approximately $2 \mathrm{Ci}$ Mo-99 and all other fission products will be produced by irradiating $5 \mathrm{~L}$ of a uranyl sulfate solution at the linac. Additionally, the effect of a high radiation field on Mo redox chemistry will be studied in the mini-SHINE experiments because, if less Mo is adsorbed or recovered on the titania column than what is expected, a portion of Mo(VI) may have been reduced to $\mathrm{Mo}(\mathrm{IV})$ or $\mathrm{Mo}(\mathrm{V})$. If this is the case, an oxidizing agent, such as potassium permanganate, can be used to ensure Mo is present as $\mathrm{Mo}(\mathrm{VI})$. 


\section{CONCLUSIONS AND FUTURE WORK}

Several column designs have been generated for the SHINE target solution configurations, and down-scale column designs have been tested using non-irradiated uranyl sulfate solutions with stable Mo and tracer Mo-99. Overall, the down-scale experiments showed that any of the five potential target solution configurations can be used to design a column with the appropriate parameters needed for good Mo adsorption and recovery. During the down-scale column experiments, two important factors were identified to increase Mo recovery:

(1) decreasing the stripping velocity by $50 \%$ compared to the loading velocity and (2) heating the strip solution to $70^{\circ} \mathrm{C}$. Both factors will be implemented for the plant-scale operation.

Three parameters have been discussed that affect column efficiency-Mo concentration, uranium concentration, and feed flow rate. From a Mo-recovery perspective, target-solution designs with the highest power density (and, thus, the highest Mo concentrations), even with high uranium concentrations, will require the lowest volume columns. For example, the plantscale column designs for the $146.8 \mathrm{~g}-\mathrm{U} / \mathrm{L}$ uranyl sulfate solution with a Mo concentration of $3.55 \times 10^{-3} \mathrm{mM}$ are the most efficient. For the recovery of Mo in 2 hours, the recommended column is $10 \mathrm{~cm} \times 14 \mathrm{~cm}$ (ID x L) utilizing $\sim 1.4 \mathrm{~kg}$ of sorbent with a pressure drop of $0.37 \mathrm{~atm}$. The projected acid wash volume for this design is $5.5 \mathrm{~L}$, water wash is $5.5 \mathrm{~L}$, and the Mo-product volume is projected to be between 22 and $33 \mathrm{~L}$. For any of the other target solution configurations, the plant-scale column designs with internal diameters of $10-12 \mathrm{~cm}$ for $2-\mathrm{h}$ loading are the best options because they are the smallest columns and will minimize wash and waste volumes. Increasing the loading time was also discussed to increase overall column efficiency, but at this point, it is not being implemented.

Modifications to the current plant-scale column designs will most likely occur after results from the mini-SHINE experiments are obtained. The effect of potential competing components on Mo adsorption and recovery may increase the column sizes slightly; however, the length of the MTZ has already been increased by $10 \%$ to account for system problems. As a result, increasing the column size may not be necessary. Additionally, an oxidizing agent may need to be added to one or more steps during the plant-scale operation to ensure that Mo is present as $\mathrm{Mo}(\mathrm{VI})$.

Once the final SHINE target solution configuration has been determined, Langmuir data will be obtained for the proper uranium concentration and temperature. Additionally, if modifications are needed based on results from the mini-SHINE experiments, those will be implemented as well. 


\section{REFERENCES}

[1] Xu, T., and Pruess, K. "On Fluid Flow and Mineral Alteration in Fractured Caprock of Magmatic Hydrothermal Systems.” J. Geophys. Res. 106(B2): doi:

10.1029/2000JB900356 (2001).

[2] Marcus, Y. Ion Properties. New York: Marcel Dekker, Inc., p. 259 (1997).

[3] Orban, E., Martin, K. B., Boyle, J. S., Heiks, J. R., and Jones, L. V. "Physical Properties of Aqueous Uranyl Sulfate Solutions from 20 to 90." J. Phys. Chem. 60, 413-415 (1956).

[4] McDuffie, H. F. "Properties of Aqueous Fuel Solutions," in Aqueous Homogeneous Reactors. Chapter 3, Ed., J. E. Lane (1960).

[5] Rhodes, F. H., and Barbour, C. B. "The Viscosities of Mixtures of Sulfuric Acid and Water." Ind. Eng. Chem. 15, 850 (1923).

[6] Chung, S.F., and C.Y. Wen. "Longitudinal Dispersion of Liquid Flowing through Fixed and Fluidized Beds," AIChE J. 14, 857-866 (1968).

[7] Wilson, E. J., and Geankoplis, C. "Liquid Mass Transfer at Very Low Reynolds Numbers in Packed Beds." Ind. Eng. Chem. Fundament. 5 (1): 9-14 (1966).

[8] Langmuir, I. "The Constitution and Fundamental Properties of Solids and Liquids. Part I Solids." J. Amer. Chem. Soc. 38, 2221-2295 (1916). 


\section{APPENDIX A:}

PLANT-SCALE COLUMN DESIGNS FOR THE POTENTIAL SHINE TARGET SOLUTION CONFIGURATIONS WITH LOADING TIMES OF 4 AND 6 HOURS 
This page intentionally left blank 


\section{APPENDIX A:}

\section{PLANT-SCALE COLUMN DESIGNS FOR THE POTENTIAL SHINE TARGET SOLUTION CONFIGURATIONS WITH LOADING TIMES OF 4 AND 6 HOURS}

TABLE A-1 Preliminary Designs for Recovery of Mo from $395 \mathrm{~L}$ of $90 \mathrm{~g}$-U/L with $1.78 \times 10^{-3} \mathrm{mM}$ Mo at $60^{\circ} \mathrm{C}(\mathrm{S110}, 99.9 \%$ recovery, 4-h loading time, $1.7-\mathrm{L} / \mathrm{min}$ rate $)$

\begin{tabular}{cccccccc}
\hline $\begin{array}{c}\text { Column ID } \\
(\mathrm{cm})\end{array}$ & $\begin{array}{c}\text { Velocity } \\
(\mathrm{cm} / \mathrm{min})\end{array}$ & $\begin{array}{c}\mathrm{MTZ}_{0.1 \%} \\
(\mathrm{~cm})\end{array}$ & $\begin{array}{c}\text { Column } \\
\text { Length } \\
(\mathrm{cm})\end{array}$ & $\begin{array}{c}\text { Column } \\
\text { Volume } \\
(\mathrm{mL})\end{array}$ & $\begin{array}{c}\text { Sorbent } \\
\text { Weight } \\
(\mathrm{g})\end{array}$ & $\begin{array}{c}\Delta \mathrm{P} \\
(\mathrm{atm})\end{array}$ & $\begin{array}{c}\text { Mo-99/ } \\
\text { Sorbent } \\
\text { Mass (Ci/g) }\end{array}$ \\
\hline & & & & & & & \\
10 & 20.96 & 18.07 & 19 & 1492 & 1940 & 0.6 & 2.58 \\
12 & 14.55 & 12.64 & 14 & 1583 & 2058 & 0.31 & 2.43 \\
15 & 9.31 & 8.19 & 9 & 1590 & 2068 & 0.13 & 2.42 \\
20 & 5.24 & 4.73 & 6 & 1885 & 2450 & 0.05 & 2.04 \\
25 & 3.35 & 3.13 & 4 & 1963 & 2553 & 0.02 & 1.96 \\
\hline
\end{tabular}

TABLE A-2 Preliminary Designs for Recovery of Mo from $395 \mathrm{~L}$ of $90 \mathrm{~g}$-U/L with $1.78 \times 10^{-3} \mathrm{mM}$ Mo at $60^{\circ} \mathrm{C}(\mathrm{S110}, 99.9 \%$ recovery, 6-h loading time, 1.1-L/min rate)

\begin{tabular}{cccccccc}
\hline $\begin{array}{c}\text { Column ID } \\
(\mathrm{cm})\end{array}$ & $\begin{array}{c}\text { Velocity } \\
(\mathrm{cm} / \mathrm{min})\end{array}$ & $\begin{array}{c}\mathrm{MTZ}_{0.1 \%} \\
(\mathrm{~cm})\end{array}$ & $\begin{array}{c}\text { Column } \\
\text { Length } \\
(\mathrm{cm})\end{array}$ & $\begin{array}{c}\text { Column } \\
\text { Volume } \\
(\mathrm{mL})\end{array}$ & $\begin{array}{c}\text { Sorbent } \\
\text { Weight } \\
(\mathrm{g})\end{array}$ & $\begin{array}{c}\Delta \mathrm{P} \\
(\mathrm{atm})\end{array}$ & $\begin{array}{c}\text { Mo-99/ } \\
\text { Sorbent } \\
\text { Mass (Ci/g) }\end{array}$ \\
\hline & & & & & & & \\
10 & 13.97 & 14.88 & 16 & 1257 & 1634 & 0.34 & 3.06 \\
12 & 9.7 & 10.42 & 12 & 1357 & 1764 & 0.17 & 2.83 \\
15 & 6.21 & 6.77 & 8 & 1414 & 1838 & 0.07 & 2.72 \\
20 & 3.49 & 3.93 & 5 & 1571 & 2042 & 0.03 & 2.45 \\
\hline
\end{tabular}

TABLE A-3 Preliminary Designs for Recovery of Mo from 257.7 $\mathrm{L}$ of 104.2 g-U/L with $2.35 \times 10^{-3} \mathrm{mM}$ Mo at $60^{\circ} \mathrm{C}(\mathrm{S110}, 99.9 \%$ recovery, 4 -h loading time, $1.1-\mathrm{L} / \mathrm{min}$ rate)

\begin{tabular}{cccccccc}
\hline $\begin{array}{c}\text { Column ID } \\
(\mathrm{cm})\end{array}$ & $\begin{array}{c}\text { Velocity } \\
(\mathrm{cm} / \mathrm{min})\end{array}$ & $\begin{array}{c}\mathrm{MTZ}_{0.1 \%} \\
(\mathrm{~cm})\end{array}$ & $\begin{array}{c}\text { Column } \\
\text { Length } \\
(\mathrm{cm})\end{array}$ & $\begin{array}{c}\text { Column } \\
\text { Volume } \\
(\mathrm{mL})\end{array}$ & $\begin{array}{c}\text { Sorbent } \\
\text { Weight } \\
(\mathrm{g})\end{array}$ & $\begin{array}{c}\Delta \mathrm{P} \\
(\mathrm{atm})\end{array}$ & $\begin{array}{c}\text { Mo-99/ } \\
\text { Sorbent } \\
\text { Mass (Ci/g) }\end{array}$ \\
\hline & & & & & & & \\
8 & 21.36 & 20 & 21 & 1056 & 1372 & 0.7 & 3.14 \\
10 & 13.67 & 12.7 & 14 & 1100 & 1429 & 0.3 & 3.02 \\
15 & 6.08 & 5.53 & 6.5 & 1149 & 1493 & 0.06 & 2.89 \\
20 & 3.42 & 3.19 & 4 & 1257 & 1634 & 0.02 & 2.64 \\
\hline
\end{tabular}


TABLE A-4 Preliminary Designs for Recovery of Mo from $257.7 \mathrm{~L}$ of $104.2 \mathrm{~g}-\mathrm{U} / \mathrm{L}$ with $2.35 \times 10^{-3} \mathrm{mM}$ Mo at $60^{\circ} \mathrm{C}(\mathrm{S110}, 99.9 \%$ recovery, 6 -h loading time, $0.7-\mathrm{L} / \mathrm{min}$ rate)

\begin{tabular}{cccccccc}
\hline $\begin{array}{c}\text { Column ID } \\
(\mathrm{cm})\end{array}$ & $\begin{array}{c}\text { Velocity } \\
(\mathrm{cm} / \mathrm{min})\end{array}$ & $\begin{array}{c}\mathrm{MTZ}_{0.1 \%} \\
(\mathrm{~cm})\end{array}$ & $\begin{array}{c}\text { Column } \\
\text { Length } \\
(\mathrm{cm})\end{array}$ & $\begin{array}{c}\text { Column } \\
\text { Volume } \\
(\mathrm{mL})\end{array}$ & $\begin{array}{c}\text { Sorbent } \\
\text { Weight } \\
(\mathrm{g})\end{array}$ & $\begin{array}{c}\Delta \mathrm{P} \\
(\mathrm{atm})\end{array}$ & $\begin{array}{c}\text { Mo-99/ } \\
\text { Sorbent } \\
\text { Mass }(\mathrm{Ci} / \mathrm{g})\end{array}$ \\
\hline & & & & & & & \\
8 & 14.24 & 15.6 & 17 & 855 & 1111 & 0.38 & 3.88 \\
10 & 9.11 & 10 & 11 & 864 & 1123 & 0.16 & 3.84 \\
15 & 4.05 & 4.6 & 5.5 & 972 & 1264 & 0.03 & 3.41 \\
20 & 2.28 & 2.67 & 3.5 & 1100 & 1429 & 0.01 & 3.02 \\
\hline
\end{tabular}

TABLE A-5 Preliminary Designs for Recovery of Mo from 178.3 L of 124.8 g-U/L with $2.98 \times 10^{-3} \mathrm{mM}$ Mo at $60^{\circ} \mathrm{C}(\mathrm{S110}, 99.9 \%$ recovery, 4 -h loading time, $0.7-\mathrm{L} / \mathrm{min}$ rate)

\begin{tabular}{cccccccc}
\hline $\begin{array}{c}\text { Column ID } \\
(\mathrm{cm})\end{array}$ & $\begin{array}{c}\text { Velocity } \\
(\mathrm{cm} / \mathrm{min})\end{array}$ & $\begin{array}{c}\mathrm{MTZ}_{0.1 \%} \\
(\mathrm{~cm})\end{array}$ & $\begin{array}{c}\text { Column } \\
\text { Length } \\
(\mathrm{cm})\end{array}$ & $\begin{array}{c}\text { Column } \\
\text { Volume } \\
(\mathrm{mL})\end{array}$ & $\begin{array}{c}\text { Sorbent } \\
\text { Weight } \\
(\mathrm{g})\end{array}$ & $\begin{array}{c}\Delta \mathrm{P} \\
(\mathrm{atm})\end{array}$ & $\begin{array}{c}\text { Mo-99/ } \\
\text { Sorbent } \\
\text { Mass (Ci/g) }\end{array}$ \\
\hline 8 & 14.78 & 17.27 & 18 & 905 & 1176 & 0.44 & 3.21 \\
10 & 9.46 & 11.17 & 12 & 942 & 1225 & 0.19 & 3.08 \\
12 & 6.57 & 7.8 & 9 & 1018 & 1323 & 0.1 & 2.85 \\
15 & 4.2 & 5.13 & 6 & 1060 & 1378 & 0.04 & 2.74 \\
\hline
\end{tabular}

TABLE A-6 Preliminary Designs for Recovery of Mo from 178.3 $\mathrm{L}$ of $124.8 \mathrm{~g}-\mathrm{U} / \mathrm{L}$ with $2.98 \times 10^{-3} \mathrm{mM}$ Mo at $60^{\circ} \mathrm{C}(\mathrm{S110}, 99.9 \%$ recovery, 6 -h loading time, $0.5-\mathrm{L} / \mathrm{min}$ rate)

\begin{tabular}{cccccccc}
\hline $\begin{array}{c}\text { Column ID } \\
(\mathrm{cm})\end{array}$ & $\begin{array}{c}\text { Velocity } \\
(\mathrm{cm} / \mathrm{min})\end{array}$ & $\begin{array}{c}\mathrm{MTZ}_{0.1 \%} \\
(\mathrm{~cm})\end{array}$ & $\begin{array}{c}\text { Column } \\
\text { Length } \\
(\mathrm{cm})\end{array}$ & $\begin{array}{c}\text { Column } \\
\text { Volume } \\
(\mathrm{mL})\end{array}$ & $\begin{array}{c}\text { Sorbent } \\
\text { Weight } \\
(\mathrm{g})\end{array}$ & $\begin{array}{c}\Delta \mathrm{P} \\
(\mathrm{atm})\end{array}$ & $\begin{array}{c}\text { Mo-99/ } \\
\text { Sorbent } \\
\text { Mass }(\mathrm{Ci} / \mathrm{g})\end{array}$ \\
\hline & & & & & & & \\
6 & 17.52 & 25.34 & 26 & 735 & 956 & 0.75 & 3.95 \\
8 & 9.85 & 14.37 & 15 & 754 & 980 & 0.24 & 3.85 \\
10 & 6.31 & 9.27 & 10 & 785 & 1021 & 0.1 & 3.70 \\
15 & 2.8 & 4.27 & 5 & 884 & 1149 & 0.02 & 3.29 \\
\hline
\end{tabular}


TABLE A-7 Preliminary Designs for Recovery of Mo from $262 \mathrm{~L}$ of $130 \mathrm{~g}$-U/L with $2.10 \times 10^{-3} \mathrm{mM}$ Mo at $80^{\circ} \mathrm{C}(\mathrm{S110}, 99.9 \%$ recovery, 4-h loading time, 1.1-L/min rate)

\begin{tabular}{cccccccc}
\hline $\begin{array}{c}\text { Column ID } \\
(\mathrm{cm})\end{array}$ & $\begin{array}{c}\text { Velocity } \\
(\mathrm{cm} / \mathrm{min})\end{array}$ & $\begin{array}{c}\mathrm{MTZ}_{0.1 \%} \\
(\mathrm{~cm})\end{array}$ & $\begin{array}{c}\text { Column } \\
\text { Length } \\
(\mathrm{cm})\end{array}$ & $\begin{array}{c}\text { Column } \\
\text { Volume } \\
(\mathrm{L})\end{array}$ & $\begin{array}{c}\text { Sorbent } \\
\text { Weight } \\
(\mathrm{g})\end{array}$ & $\begin{array}{c}\Delta \mathrm{P} \\
(\mathrm{atm})\end{array}$ & $\begin{array}{c}\text { Mo-99/ } \\
\text { Sorbent } \\
\text { Mass (Ci/g) }\end{array}$ \\
\hline 8 & & & & & & & \\
10 & 21.74 & 19.16 & 22 & 1.1 & 1440 & 0.55 & 2.70 \\
12 & 13.91 & 12.4 & 14 & 1.1 & 1430 & 0.23 & 2.71 \\
15 & 9.66 & 8.8 & 10 & 1.1 & 1470 & 0.12 & 2.64 \\
\hline
\end{tabular}

TABLE A-8 Preliminary Designs for Recovery of Mo from $262 \mathrm{~L} \mathrm{of} 130 \mathrm{~g}$-U/L with $2.10 \times 10^{-3} \mathrm{mM}$ Mo at $80^{\circ} \mathrm{C}(\mathrm{S110}, 99.9 \%$ recovery, 6-h loading time, $0.7-\mathrm{L} / \mathrm{min}$ rate $)$

\begin{tabular}{cccccccc}
\hline $\begin{array}{c}\text { Column ID } \\
(\mathrm{cm})\end{array}$ & $\begin{array}{c}\text { Velocity } \\
(\mathrm{cm} / \mathrm{min})\end{array}$ & $\begin{array}{c}\mathrm{MTZ}_{0.1 \%} \\
(\mathrm{~cm})\end{array}$ & $\begin{array}{c}\text { Column } \\
\text { Length } \\
(\mathrm{cm})\end{array}$ & $\begin{array}{c}\text { Column } \\
\text { Volume } \\
(\mathrm{L})\end{array}$ & $\begin{array}{c}\text { Sorbent } \\
\text { Weight } \\
(\mathrm{g})\end{array}$ & $\begin{array}{c}\Delta \mathrm{P} \\
(\mathrm{atm})\end{array}$ & $\begin{array}{c}\text { Mo-99/ } \\
\text { Sorbent } \\
\text { Mass (Ci/g) }\end{array}$ \\
\hline & & & & & & & \\
6 & 25.76 & 28.32 & 31 & 0.9 & 1180 & 0.96 & 3.29 \\
8 & 14.49 & 16 & 18 & 0.9 & 1180 & 0.31 & 3.29 \\
10 & 9.27 & 10.4 & 12 & 0.9 & 1170 & 0.13 & 3.32 \\
12 & 6.44 & 7.2 & 8 & 0.9 & 1180 & 0.06 & 3.29 \\
15 & 4.12 & 4.71 & 6 & 0.97 & 1260 & 0.03 & 3.08 \\
\hline
\end{tabular}

TABLE A-9 Preliminary Designs for Recovery of Mo from 142.3 L of 146.8 g-U/L with $3.55 \times 10^{-3} \mathrm{mM}$ Mo at $60^{\circ} \mathrm{C}(\mathrm{S110}, 99.9 \%$ recovery, 4 -h loading time, $0.6-\mathrm{L} / \mathrm{min}$ rate)

\begin{tabular}{cccccccc}
\hline $\begin{array}{c}\text { Column ID } \\
(\mathrm{cm})\end{array}$ & $\begin{array}{c}\text { Velocity } \\
(\mathrm{cm} / \mathrm{min})\end{array}$ & $\begin{array}{c}\mathrm{MTZ}_{0.1 \%} \\
(\mathrm{~cm})\end{array}$ & $\begin{array}{c}\text { Column } \\
\text { Length } \\
(\mathrm{cm})\end{array}$ & $\begin{array}{c}\text { Column } \\
\text { Volume } \\
(\mathrm{mL})\end{array}$ & $\begin{array}{c}\text { Sorbent } \\
\text { Weight } \\
(\mathrm{g})\end{array}$ & $\begin{array}{c}\Delta \mathrm{P} \\
(\mathrm{atm})\end{array}$ & $\begin{array}{c}\text { Mo-99/ } \\
\text { Sorbent } \\
\text { Mass (Ci/g) }\end{array}$ \\
\hline & & & & & & & \\
6 & 20.97 & 25.21 & 26 & 735 & 956 & 0.95 & 3.75 \\
8 & 11.8 & 14.27 & 15 & 754 & 980 & 0.31 & 3.66 \\
10 & 7.55 & 9.19 & 10 & 785 & 1021 & 0.13 & 3.52 \\
15 & 3.36 & 4.2 & 5 & 884 & 1149 & 0.03 & 3.12 \\
\hline
\end{tabular}


TABLE A-10 Preliminary Designs for Recovery of Mo from 142.3 L of 146.8 g-U/L with $3.55 \times 10^{-3} \mathrm{mM}$ Mo at $60^{\circ} \mathrm{C}(\mathrm{S110}, 99.9 \%$ recovery, 6 -h loading time, $0.4-\mathrm{L} / \mathrm{min}$ rate)

\begin{tabular}{cccccccc}
\hline $\begin{array}{c}\text { Column ID } \\
(\mathrm{cm})\end{array}$ & $\begin{array}{c}\text { Velocity } \\
(\mathrm{cm} / \mathrm{min})\end{array}$ & $\begin{array}{c}\mathrm{MTZ}_{0.1 \%} \\
(\mathrm{~cm})\end{array}$ & $\begin{array}{c}\text { Column } \\
\text { Length } \\
(\mathrm{cm})\end{array}$ & $\begin{array}{c}\text { Column } \\
\text { Volume } \\
(\mathrm{mL})\end{array}$ & $\begin{array}{c}\text { Sorbent } \\
\text { Weight } \\
(\mathrm{g})\end{array}$ & $\begin{array}{c}\Delta \mathrm{P} \\
(\mathrm{atm})\end{array}$ & $\begin{array}{c}\text { Mo-99/ } \\
\text { Sorbent } \\
\text { Mass (Ci/g) }\end{array}$ \\
\hline & & & & & & & \\
5 & 20.13 & 30.1 & 31 & 609 & 791 & 1.09 & 4.54 \\
6 & 13.98 & 20.96 & 22 & 622 & 809 & 0.54 & 4.44 \\
8 & 7.86 & 11.87 & 13 & 653 & 849 & 0.18 & 4.23 \\
10 & 5.03 & 7.67 & 9 & 707 & 919 & 0.08 & 3.91 \\
\hline
\end{tabular}





\section{Argonne}

Chemical Sciences and Engineering Division

Argonne National Laboratory

9700 South Cass Avenue, Bldg. 205

Argonne, IL 60439-4837

www.anl.gov

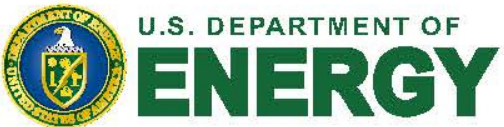

Argonne National Laboratory is a U.S. Department of Energy

laboratory managed by UChicago Argonne, LLC 